Article

\title{
Can EU Civil Society Elites Burst the Brussels Bubble? Civil Society Leaders' Career Trajectories
}

\author{
Jayeon Lindellee * and Roberto Scaramuzzino \\ School of Social Work, Lund University, Lund 211 00, Sweden; E-Mails: jayeon.lindellee@soch.lu.se (J.L.), \\ roberto.scaramuzzino@soch.lu.se (R.S.) \\ * Corresponding author
}

Submitted: 9 March 2020 | Accepted: 14 May 2020 | Published: 4 September 2020

\begin{abstract}
The Brussels-based civil society organizations (CSOs) have been conceived by the EU to act as a bridge between the bureaucratic elites and the citizens of Europe. The institutionalized presence of the major EU-based CSOs has, however, called their legitimacy into question, as exemplified by notions such as 'revolving doors' implying homogeneous social, educational, and professional backgrounds shared by both EU officials and CSO leaders. This article therefore asks the following questions: To what extent do the leaders of EU-based CSOs merely reproduce the types of capital that mirror those of the political elites in the so-called 'Brussels bubble'? To what extent do the CSO leaders bring in other sets of capital and forms of recognition that are independent of the Brussels game? How can we explain differences in the salience of EU capital found across policy areas, types of leadership positions, and types of organizations? Empirically, this article qualitatively analyzes the career trajectories of 17 leaders of EU-based peak CSOs that are active in social and environmental policy areas. Despite the highly integrated and institutionalized characteristics shared by all organizations, we find diversity in the composition of the leaders in terms of the extent to which their career trajectories are embedded in the EU arena.
\end{abstract}

\section{Keywords}

capital; career trajectory; civil society organizations; EU institutions; EU Policies; political elites

\section{Issue}

This article is part of the issue "Civil Society Elites" edited by Håkan Johansson (Lund University, Sweden) and Anders Uhlin (Lund University, Sweden).

(C) 2020 by the authors; licensee Cogitatio (Lisbon, Portugal). This article is licensed under a Creative Commons Attribution 4.0 International License (CC BY).

\section{Introduction}

The project of European integration has entailed not only the creation of new institutional actors such as the European Commission, European Court of Justice, and European Parliament, but also a new constellation of collective actors such as interest groups and civil society organizations (CSOs) established at the EU level. This new socio-political space has attracted the interest of social scientists seeking to analyze these new interactions and power relations (Coen \& Richardson, 2009; Fligstein, 2008; Georgakakis \& Rowell, 2013; Johansson \& Kalm, 2015; Magone, Laffan, \& Schweiger, 2016). Departing from an understanding of the EU arena as a Bourdieusian bureaucratic field in the making (Bourdieu,
1994; Georgakakis, 2017; Georgakakis \& Rowell, 2013), this article sets out to explore the career trajectories of EU-based CSOs' leaders in relation to wider field dynamics that structure the relative positions of different actors.

The aim of this article is to analyze to what extent previous knowledge about the main oppositional dynamics in the field of Eurocracy between the 'insiders' and 'outsiders' also applies to EU-based civil society. The insiders in the EU's socio-political field have been conceptualized as the high-level civil servants dominant in the EU institutions with their bureaucratic backgrounds, as well as a range of political actors who work closely with the EU institutions in consensual and depoliticized ways, seizing the access to the EU's highly specialized and complex 
policy processes. The outsiders, on the other hand, have been conceptualized as the actors who employ more contentious strategies and who are more likely to mobilize grassroots constituencies in national contexts (Dür \& Mateo, 2016; Georgakakis \& Rowell, 2013; Greenwood, 2007). As intermediary actors, EU-based CSOs have been conceived by the EU to act as a bridge between the bureaucratic elites in the EU and the citizens of Europe (European Commission, 2001; Kohler-Koch \& Rittberger, 2007; Smismans, 2003; Trenz, 2009). They have, in fact, been acting as agents of policy integration and dissemination of EU policy ideas, especially in areas such as human rights, anti-discrimination, environmental protection, and gender equality (Ruzza, 2007, 2014, 2019). By studying the (broadly-defined) career trajectories of the leaders, we can derive a set of skills, types of capital, and forms of recognition and status that are relevant in the field of EU civil society and discuss the extent to which the fault line between the insiders and outsiders is observed at the level of individual leaders' career trajectories.

We will answer the following research questions:

- To what extent do we find specific EU capital in the career trajectories of the major CSO leaders in the social and environmental policy areas?

- What other sets of capital and forms of recognition do we find in the career trajectories of the CSO leaders that are rather independent of the Brussels game?

- How can we explain different forms of capital in different leaders' trajectories?

Empirically, this article is based on a study of the career trajectories of 17 leaders of peak EU-based CSOs active in the two policy areas of social policy and environmental policy. By 'peak organizations' we refer to organizations that have access to a disproportionate amount of resources and/or enjoy high status and recognition within civil society and/or by EU-institutions. The data are based on short biographies of the presidents and directors of the identified CSOs, which provide information regarding their career trajectories.

\section{Previous Research}

\subsection{Democratic Representation, Power Structures and Capital in the Field of EU Civil Society}

Civil society refers to a societal sphere separate from the state, the market and the family that is populated by a variety of collective actors, including organizations, networks and movements. This article focuses on CSOs in terms of formal organizations that belong to the sphere of civil society. Among these organizations, we find interest groups, social movement organizations and other forms of non-governmental and non-profit actors (Meeuwisse \& Scaramuzzino, 2019).
The EU-based CSOs have emerged as a set of actors that gained access to EU institutions as the EU expanded its regulatory competences in different areas. The important role that the Brussels-based CSOs have played in the evolution of the EU's competence and institutionalized presence in many policy areas naturally calls for a debate about democratic representation. Although EU-based CSOs existed earlier, it was the EU's 'participatory turn' during the 1990s that gave them a clear role in the deliberative policy processes envisioned by the EU institutions (European Commission, 2001). The general expectation concerning advocacy strategies is that CSOs would be more likely to employ outsider strategies (e.g., demonstrations) as opposed to business actors, who would be more inclined to use insider strategies (e.g., lobbying; Dür \& Mateo, 2016; Maloney, Jordan, \& McLaughlin, 1994). Instead, the major expansion of the EU-based CSOs was aided by the financial and ideational support of the European Commission. This meant that many organizations acquired rather institutionalized positions vis-à-vis the EU institutions and have taken on the role of consultative bodies, rather than the role of political agents taking matters to the streets (Cullen, 2003; Greenwood, 2007; Michel, 2013; Ruzza, 2007). Scholars have thus raised the issue of the representativeness of the CSO leaders, and there has been a great deal of empirical research looking into the actual mechanisms and practices of representation and the representational claims of non-elected representatives (Johansson \& Lee, 2014; Kröger \& Friedrich, 2012).

Despite the salience of these debates, few previous studies have looked into the actual profiles of the EU-based CSO leaders. Notions such as 'revolving doors' and 'Brussels' bubble' have been used to illustrate the homogeneous social, educational, and professional backgrounds among EU officials and the CSO leaders active at the EU level (Dialer \& Richter, 2019). It has also been argued that the system of representation exemplified by the European Transparency Initiative (European Commission, 2006) is in fact a result of co-production between the EU institutions and interest groups whose leaders share not only the same backgrounds, but also a common vision of European integration (Michel, 2013). However, these sweeping statements might obscure the diversity that might be found among the leaders of EU-based CSOs. This article thus attempts to empirically scrutinize the career trajectories of the leaders of peak EU-based CSOs.

The debate on the representativeness of EU-based CSOs and their leaders can be connected to the previously mentioned notion that the incumbents in the field of EU civil society-the actors who have close access to the EU institutions-prioritize consensual and coordinative strategies in a bureaucratic and depoliticized manner, rather than confrontational and politicized strategies that rely on grassroots mobilization. This preference for insider strategies implies that being able to provide expertise on specific policy issues for the demands and 
political frameworks of the EU's institutional actors in a tailored manner is considered important capital (Oleart \& Bouza, 2018, p. 884). It could be expected that the importance of such capital could be directly translated to the profiles of the leaders of EU-based CSOs. Yet, previous empirical studies have shown that among the incumbents in the field of EU civil society we can also observe organizations that are more nationally or internationally anchored, profiling themselves as true grassroots organizations, rather than professionalized participants in policy-centered dialogues with EU institutions (Johansson \& Lee, 2015).

Thus, the question of which types of capital are valued in the field of EU civil society cannot be easily answered. Furthermore, as demonstrated by Oleart and Bouza's (2018) study on the involvement of EU-based CSOs in the European Citizens' Initiative, the insideroutsider divide alone does not fully explain the repertoire of advocacy strategies employed by some of the incumbent CSOs, as instruments such as the $\mathrm{ECl}$ invite the CSOs to engage in novel constellations of collaborations and campaign activities. In order to understand the constantly changing patterns of cooperation and competition among CSOs in the field of EU civil society, studying the profiles of individual leaders could provide a novel insight into the types of capital that are valued and the kinds of social institutions, skills and experiences that lead to top positions in EU-based CSOs.

\subsection{Studying Career Trajectories in Order to Understand Positions within the EU Field}

The contribution of this study is twofold. First, while previous studies have looked extensively into the career trajectories and professional backgrounds of formal representatives of EU institutions as well as a various groups of adjacent players interacting with these EU institutions such as experts and representatives of interest groups and lobbying organizations (Beauvallet \& Michon, 2013; Georgakakis \& Lebaron, 2018; Robert, 2013), few studies have explored the careers of EU-based CSO leaders.

Second, traditional approaches in studies of elites tend to explore the link between a given elite position and individuals' social origins such as family backgrounds. The present study of career trajectories of EU-based CSO leaders instead draws on the tradition of prosopographical studies of elites developed by C. Wright Mills and Pierre Bourdieu (Ellersgaard \& Larsen, 2020). Common to these empirical studies is that beyond the formal positions that individual leaders occupy as of today, one pays attention to their career trajectories. This provides a glimpse into the social processes lying behind their elite positions. The career trajectories might thus reveal the ways in which the individuals build their own authority and pursue their organizational as well as professional interests (Georgakakis \& Rowell, 2013). Studying the prosopography of individual leaders of selected CSOs can thus help us understand the field of civil society at the EU level by identifying the patterns of career paths from which we can infer what types of social institutions, skills, and recognition play important roles in the reproduction of elites (Khan, 2012, p. 371).

\section{Theoretical Departing Point}

\subsection{The EU as a Bureaucratic Field in the Making}

The development of the EU resembles a bureaucratic field in the making in multiple respects (Bourdieu, 1994). The institutionalization of European integrationist practices has increased the complexity in the thick web of actors interacting at the EU level and has led to the concentration in Brussels of different types of actors with diverse types of capital. The development of the EU's external border policy can be aptly compared to the domination of physical force that Bourdieu explained as one of the core elements of the state-building process ("Capital of physical force"). The EU's expanding internal market, the adoption of the European Monetary Union, and the adoption of the euro as the common currency all strengthen the symbolic value of the EU as a unitary territory ("Economic capital"). The vision and identity of a globalized, Europeanized, cosmopolitan Europe is advocated as a "universal" interest for Europeans and unifies the EU institutions and civil society actors within the EU arena ("Information/cultural capital"; Bourdieu, 1994)

Bourdieu-inspired field-theory approaches have been frequently applied in sociological studies of the EU arena focusing on interactions between various collective actors (Coen \& Richardson, 2009; Fligstein, 2008; Michel, 2013; Vauchez \& de Witte, 2013). As a novel political environment, the studies of particular power dynamics and network structures within the EU arena identified the inner core of this field, epitomized in notions such as 'permanent Eurocrats' who are equipped with specific sets of knowledge, expertise, and social skills (Georgakakis \& Rowell, 2013). The importance of informal rules and processes governing the EU's policy and legislative processes (Héritier, 2012; Stacey, 2010) can give the so-called 'insiders' in the EU arena strategic advantages over those who only intermittently visit Brussels. This field-specific dynamic has been understood to give rise to the core, bureaucratic elites in Brussels who actively seek to consolidate the EU as a bureaucratic field, embodying the active agents striving to establish and represent a common 'European' interest (Bourdieu, 1994; Georgakakis, 2017; Georgakakis \& Rowell, 2013).

In this context, the specific 'EU capital' can be understood as comprising a range of different types of capital that can be effectively translated into "symbolic capital" in the EU arena (Bourdieu, 1994, pp. 8-9). For a given skill, status, recognition, or experience to gain this symbolic power in the field of Eurocracy, it is the acknowledgement, recognition, and even accreditation by the EU institutions that matters. This is because it is the EU 
institutions that have a clear "authority of nomination" (Bourdieu, 1994, pp. 10-11). The EU institutions are, in other words, the primary supplier of the EU capital, and one of the concrete manifestations of such capital with regards to the EU-based CSOs is when they gain official status as a consultative body. By being invited to the EU's policy discussions and formal processes as official representatives of CSOs, they are officially recognized as a responsible and competent agent for the project of European integration.

\subsection{Analytical Focus}

Investigating individual leaders' career trajectories is a way of understanding a given field in a dynamic way because we consider the importance of individual leaders' own career trajectories for understanding the different positions they occupy in relation to each other, which might reveal fault lines that are not obvious from merely looking at the positions of the organizations (Georgakakis \& Rowell, 2013, p. 5). This article, hence, explores to what extent the EU-based CSO leaders possess the types of capital that are EU-specific and what their career trajectories tell us about the status, forms of recognition, and experiences outside of the EU arena that can be translated into valuable capital in the field of Eurocracy.

The article aims to explore the following hypotheses informed by our theoretical understanding of the field of Eurocracy: First, we expect that the positions of the CSO leaders will mirror the broader fault line between the permanent, Brussels-based insiders and the intermittent participants in the EU arena whose reputations and capital are derived mainly from the national/international arenas. Second, related to the first point, we expect to observe what can be called 'EU capital' and its particular repertoire relevant for the CSO leaders in their career trajectories. This could be in the form of educational degrees in certain subjects and/or universities, formal employment positions in EU institutions, or other types of accreditation from EU institution with symbolic value. Third, despite the nested character of the field of CSOs at the EU level reflecting the broader oppositional dynamics in the field of Eurocracy, we expect to find other types of skills, status, and forms of recognition that are specifically important to the CSOs. This aspect sheds light on to what extent CSO leaders are embedded in the EU field and to what extent their status and authority are determined by their embeddedness in other fields (for example, national/international or academic fields). This question is motivated by previous understanding of the EU arena as a "porous" field that is easily affected by external determinants with uneven processes of integration across different policy fields (Georgakakis \& Rowell, 2013, p. 239).

The two policy areas the leaders are engaged in share some important features in their development at the EU level. In environmental protection, CSOs have been in- tegral to the presence of the EU in policy discussions. The European Commission and the European Parliament have been important institutional actors that facilitated the establishment and empowerment of the transnational, Brussels-based environmental CSOs since the 1980s, and the environmental CSOs have continuously intensified their coordinated and collective actions at the EU level, as exemplified by the European Environmental Bureau working with joint campaigns such as "Greening the Treaty" in the 1990s. The institutionalized and formalized position of the key environmental CSOs by means of being included in structured dialogues and on working committees with the European Commission and the European Parliament was utilized in turn to strengthen and reinforce the legal basis of the EU's mandate in environmental protection as a policy area through the adoption of EU directives (Cichowski, 2007, pp. 210-220).

A similar development has taken place in the establishment of the so-called 'social dimension' of the EU and the CSOs working with a diverse range of social issues. During the 1980s, the EU took a step towards institutionalizing its mandate in the social policy area, and this led to the establishment of Brussels-based CSOs seeking influence in the development of the EU's social dimension (Cullen, 2003; Greenwood, 2007; Kendall, 2009). Despite exhibiting a great diversity in the types of policy issues, causes, and groups represented by the social CSOs, we have witnessed the emergence and expansion of Brussels-based umbrella organizations and networks such as Social Platform and Civil Society Contact Group that have attempted to act as a concerted voice. Previous research looking into this particular population of organized civil society in Brussels showed that there are competing and contradictory capital-logics at play and that both interconnectedness with the EU institutions as well as autonomy from them are valued by the CSOs (Johansson \& Lee, 2015).

While both policy areas have seen the establishment of EU-based CSOs already in the 1980s, they differ when it comes to the EU mandate, which is stronger when it comes to environmental issues than in social policy. The types of CSOs in each policy area also tend to differ as the area of social policy is dominated by organizations that aim to represent specific societal groups vis-à-vis the EU institutions (e.g., women, pensioners, people with disabilities), which does not apply to the area of environmental policy. Based on these differences, we expect expert knowledge as a type of capital to be more salient in the area of environmental policy than in the area of social policy, while an activist background to be more salient in the area of social policy than in the area of environmental policy.

\section{Sampling Method and Data}

The leaders who are studied in this article are those who have gained significant symbolic capital in the field of Eurocracy by being granted privileged positions within 
EU-based CSOs and vis-à-vis the EU. This article is based on an analysis of these leaders' career trajectories.

To be able to identify the peak organizations, we have mostly made use of the Transparency Register of the EU and the database Lobbyfacts. Using a set of five indicators that allowed us a broad and complex interpretation of status and recognition in civil society at the EU-level, we sampled $308 \mathrm{EU}$-based CSOs active in different policy areas among which we identified the CSOs in the social and environmental policy fields.

The first set of two indicators measured different forms of internal status and recognition: 1) Internal resources for organizations that have at least 4 staff members (as full-time equivalents) or that have at least 910,000 euro as their budget; and 2) Internal status and recognition for organizations that are members of one of the following umbrella organizations representing the civil society sector-Civil Society Europe and Civil Society Contact Group. When it comes to external status and recognition, we used the following three indicators: 3) EU funding of at least 600,000 euro; 4) External status and recognition within specific policy areas for organizations that are included in Intergroups and EU Commission groups or that according to Lobbyfacts had had at least seven meetings with the European Commission; and 5) External status and recognition for organizations that are members of the Liaison group of the European Economic and Social Committee.

Among the 308 CSOs sampled, we chose eight CSOs for this study based on the following criteria: 1) Being active in the areas of social or environmental policy; 2) Fulfilling at least three of our five indicators; and 3) Availability of biographical information on both the president the director of the CSO.

Table 1 shows the four organizations chosen for the social policy area and the four chosen for the environmental policy area. In total we considered 17 leaders because we included two directors for the Red Cross-the director of the European Region and the director of the EU office.

While presidential positions uphold tasks of external representation, directors work on the managerial aspects of the everyday routines in the organization. A reason for choosing a small sample of presidents and directors belonging pairwise to the same organizations is that this allows us a more in-depth analysis of the CSOs they represent. This includes looking at the characteristics of the organization, e.g., if it has a strong organizational identity across different levels of governance (hereafter referred to identity-based organizations) or if it is a network or umbrella organization that has a diverse set of member organizations (hereafter referred to as umbrella organizations). We included organizations with strong identities, such as Caritas, Red Cross, Friends of the Earth (FoE), and the World Wildlife Fund (WWF), as well as umbrella organizations with various types of member organizations such as Solidar and the International Union for Conservation of Nature (IUCN), which are active also at the international level, and Social Platform and Green 10 that are exclusively operating at the EU level. We expected that these organizational characteristics might partly explain the different career trajectories of the leaders.

For each individual leader we collected biographical data based on the following sources: organizational websites, personal websites, Wikipedia, and LinkedIn. Combining different sources gives us a broader insight into the leaders' career trajectories. These sources differ in terms of their aim and target audience. Organizational websites might be keen to present the leaders in ways that fit their organizational profile, while the leader's personal website and LinkedIn profile would reflect how they want to promote themselves. We would assume that the Wikipedia article would be more neutral. The fact that certain experiences are more or less pronounced in the presentations of the leaders' profiles allows us to draw conclusions regarding the types of capital that are valued in the field, which is an important part of our aim. By combining different sources of data as much as possible, we argue that we are able to overcome certain biases in the sources and have quite accurate (although not exhaustive) information on the leaders' career trajectories.

The following analysis explores different sets of capital that are traceable in the leaders' career trajectories and disentangle those that can be related to the field of Eurocracy and those that seem to be more independent from it. By comparing these sets of capital when it comes to policy areas (social vs. environmental policy), leaders' positions (presidents vs. directors), and types of organizations (umbrella vs. identity-based), we aim at explaining the variation of the career trajectories among the leaders.

\section{Analysis}

The analysis of the biographic information of the selected individual CSO leaders was initially guided by

Table 1. CSOs whose leaders were included in the analysis by policy area.

\begin{tabular}{ll}
\hline Social policy & Environmental policy \\
\hline Solidar & International Union for Conservation of Nature \\
Social Platform & Green 10 \\
Caritas & Friends of the Earth \\
Red Cross & World Wildlife Fund \\
\hline
\end{tabular}


the theoretical interest in discerning EU capital from other types of capital. After several rounds of careful reading of the leaders' biographies, we developed a coding scheme consisting of the following six categories: Brussels or EU-specific, international experience, long-term engagement with the national branch, expert orientation, managerial competence, and activist backgrounds/charismatic leader. These codes were used explicitly in new rounds of analysis and Table 2 lists examples of items in the leaders' biographical information that were coded into the above-mentioned categories.

Based on the coding of the biographical information of the 17 leaders, Figure 1 offers a visualization of the different characteristics of the leaders' career trajectories. The figure is not based on any quantification, but rather on a qualitative interpretation of the career trajectories of the 17 leaders in relation to each other. The three labels presented along each axis should be considered as ideal-typical categories that characterize the leaders' professional experience and engagement. These categories should not be seen as being placed on a continuum in the strict sense. The end poles of the axes represent tensions between theoretically motivated 'oppositions' (expert vs. activist; national vs. EU-specific) while the categories placed in the middle (managerial competence and international) should be seen as third categories on the same axes and not as an exact middle ground between the two opposites. The horizontal axis is primarily inspired by the distinction made in previous research that examine the field of Eurocracy, in which the insider and outsider divide is known to be salient (Dür \& Mateo, 2016; Georgakakis \& Rowell, 2013). The vertical axis is partly inspired by the same body of literature in which the importance of expert knowledge of European political processes is emphasized. While it is possible to argue that the knowledge claims that could be made by a long-term activist about a specific issue is also a highly legitimate form of expertise, in this figure we consider a rather narrow definition of what we call 'expert knowledge' in the sense that the leaders have formal educational backgrounds in the subject matters within which they work.

It is evident that the self-representation of leaders, whether mediated via organizations or not, emphasizes different types of competing and complementary forms of knowledge that are pivotal to leading these EU-based CSOs in different ways. Thus, the distribution of individual leaders in the figure is partly a result of the ways in which their career backgrounds are portrayed, in many cases, in narrative forms that emphasize certain aspects of their backgrounds over others. Individuals are placed in the figure with their position and organization, followed by " $P$ " for president/chair positions and " $D$ " for directorships. The organizations written in green font are the ones active in the environment policy areas, and the ones in light blue are the social policy areas. The organizations that have underlined names are umbrella organizations, while the ones without are identity-based CSOs.

\subsection{The Horizontal Axis: EU Capital vs. Skills, Experiences, and Recognition Accumulated Outside of the EU Arena}

The horizontal axis in the figure describes the opposition between career trajectories with highly Brussels and EU-specific orientations on the right and those with more national orientations on the left. The mid-point captures international orientations.

Examples of the Brussels and EU-specific career trajectories include long-term experience in EU-level advo-

Table 2. Coding scheme.

\begin{tabular}{ll}
\hline Categories used in coding & Examples \\
\hline Brussels-or EU-specific & President/directorship and other executive positions of EU-based CSOs; Expert role \\
experience & in EU policy processes; Chair of EESC; Directorship at Brussels office of international \\
& organizations; Long-term residency in Brussels; Lawyer by training
\end{tabular}

International experience

President/directorship and other executive positions of international CSOs and other types of international organizations such as OECD, UN; Extended period of working overseas; Engagement in projects in multiple national contexts

Engagement at national level Long-term career in national branches of European/international CSOs, including volunteer engagement; Expert role in national policy processes

Expert orientation

Managerial competence
Academic degree related to specific policy areas; expert advisor role

Mid-level management positions in multiple organizations; Academic degree in business, management, leadership and communication related subjects

Activist backgrounds/charismatic Self-presentation as activist; Recognized political/religious figure leadership figure 


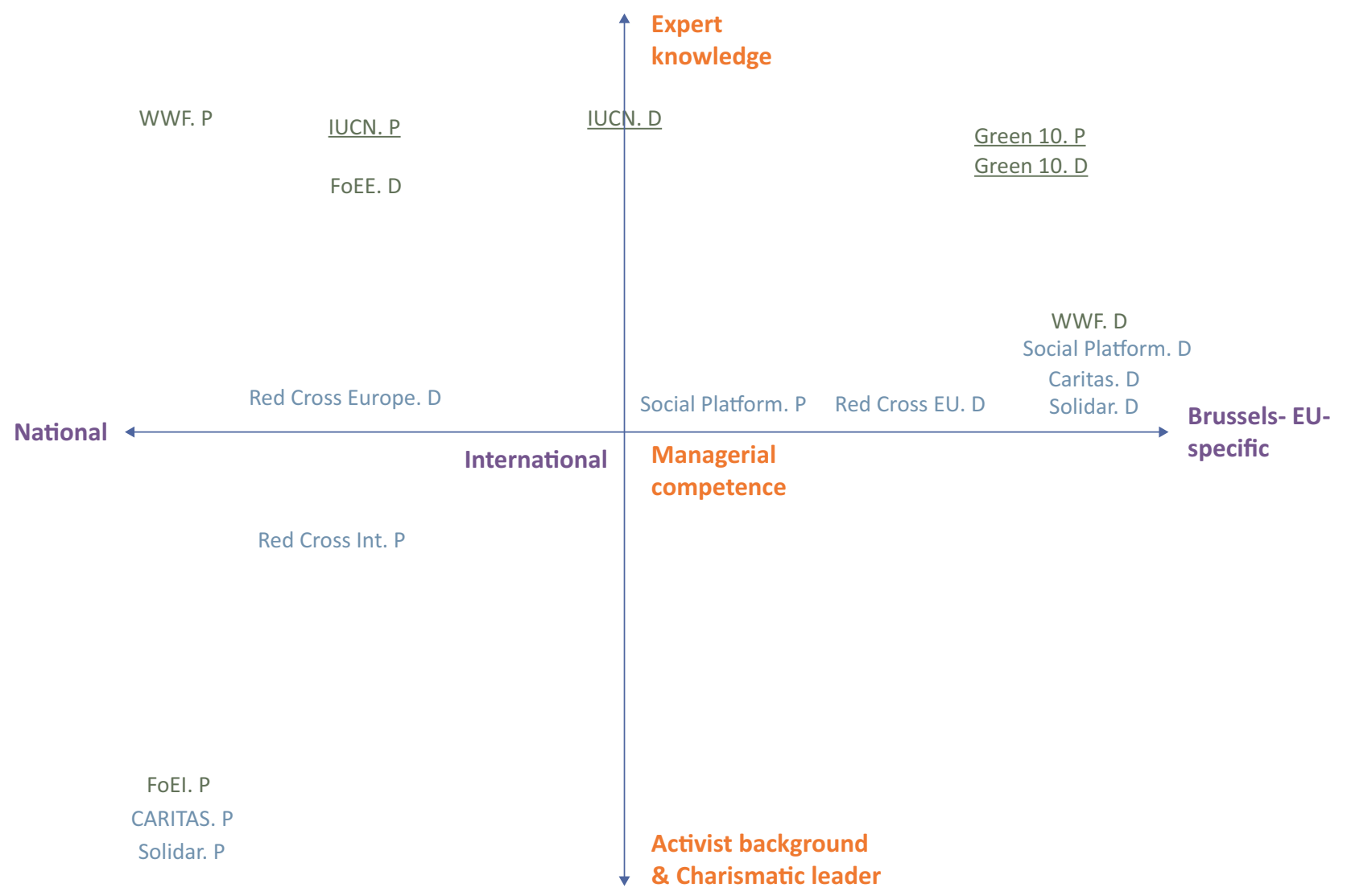

Figure 1. Types of capital in the career trajectories of EU-based CSO leaders. Note: The figure is not based on any quantification, but rather on a qualitative interpretation of the career trajectories of the 17 leaders in relation to each other.

cacy and lobbying, being invited as experts as part of the EU's common policy processes, chairing specific EU institutions such as the European Economic and Social Committee, having been either executive or representative leaders of EU-based CSOs or networks of CSOs, previously having held positions in Brussels-based offices of international organizations, having majored in the typical academic disciplines among the EU representatives, i.e., law or international relations/politics, and lastly having resided in Brussels for an extended period of time.

The other side of the horizontal axis represents the career trajectories that are concentrated in specific national contexts, and the mid-point represents professional experiences in various non-EU countries and in international arenas. Examples of national experiences include longterm engagement (often starting as volunteers) in the national branch of the CSO and having worked extensively in relation to governments and other public authorities in specific national contexts. Examples of international experiences include executive or representative positions in international CSOs and having worked in specific policy programs as experts in international organizations such as the OECD and UN institutions.

What we can see along the horizontal axis is that while the directors are dominant in the right half of the space (directors of Green 10, WWF, Social Platform, Caritas, Solidar, and Red Cross EU), the presidents are dominant in the left half of the space (presidents of the IUCN, WWF, Red Cross, Caritas, FoE, and Solidar). There are of course some 'strange birds,' such as the director of the IUCN who has been extremely active at the EU level having been closely involved in the EU's climate and energy policy, yet at the same time has been closely collaborating with the public authorities in Belgium as an expert advisor. Similarly, the president of Social Platform has been extensively engaged in advocacy and lobbying at the EU level as an executive leader of an EU-based CSO. However, he is not based in Brussels and has previously worked in other national contexts and in the private sector-which makes this president stand out from the others who are placed on the right side of the axis with more clearly Brussels-based careers.

Another interesting observation is that we find mostly umbrella organizations on the right-hand side of the axis (both president and director of Green 10 and directors of Social Platform and Solidar), whereas the identity-based CSOs are found on the left-hand side of the axis (presidents of the WWF, Red Cross, FoE, and Caritas). Experience of working in direct contact with the EU seems to be the most prominent characteristic of many directors of the umbrella CSOs, especially for the specifically EU-level organizations Green 10 and Social Platform whose leaders are placed in the upper right corner of the figure. The leaders of the international um- 
brella organizations IUCN and Solidar are more spread out, with the directors being close to the right side of the horizontal axis and the presidents being placed on the other end of the axis representing national and international orientations in their career trajectories. When it comes to the identity-based CSOs (WWF, FoE, Caritas, and Red Cross), their presidents have all developed careers outside of the EU arena. In the case of FoE Europe, its director had never even lived in Brussels or worked for any other CSO at the EU level previously.

Following a similar logic, the different profiles of the two directors of the Red Cross is a telling case. While the EU office director has previously worked in the Brussels office of a UN institutions and even within the European Commission, the biographic information about the director of the European Region of the Red Cross exhibits a much more nationally and internationally oriented career trajectory, as exemplified by long-term engagement in the organization at the national level and also having participated in projects in other non-EU countries.

\subsection{The Vertical Axis: Expert Knowledge-Managerial Competence-Activist/Charismatic Leader Identity}

The vertical axis in Figure 1 captures the different types of knowledge and experiences manifested in the selected CSO leaders' career trajectories. The placement of leaders along this axis is to be interpreted with care because some of the indicators used are arguably rather rough, such as the subject matter that the leaders had majored in as an indicator of expert knowledge. The leaders were placed on the upper half of the vertical axis if they majored in the subjects that are clearly relevant for the policy areas that the organizations work with. On the other end of the vertical axis we placed the leaders whose career trajectories are characterized by their activist backgrounds and are described as well-known figures, often with nearly heroic narratives about their lifetime commitment to issues as leaders and activists. In the middle of the vertical axis we find what is termed managerial competences, meaning that the leaders' career trajectories demonstrate high managerial competences with previously held executive roles. The leaders who have educational backgrounds in business and management, leadership, and communication subjects are positioned near this mid-point.

One salient observation is that the majority of the directors of the selected organizations can be closely placed to the mid-point of the vertical axis, indicating conspicuous managerial competence (WWF, Social Platform, Caritas, Solidar, and Red Cross). Almost all the leaders in the lower half of the vertical axis are instead presidents (FoE, Caritas, Red Cross, and Solidar). They seem to share an activist profile in the sense that they entered the civil society field as grassroots' activists and made their way up to the point where their activism became a professional career. What characterizes these leaders is that their involvement in civil society is performed within the same organization by moving up through the organization's structure over time.

Another difference is found between the organizational types along the vertical axis. The majority of the umbrella CSO leaders (Green 10, IUCN, Social Platform, and Solidar) are found in the upper-half of the vertical axis, meaning that expert knowledge on the issues they work with in their organizations and/or managerial competences are most pronounced in their educational backgrounds and professional trajectories (the only exception is the president of Solidar). On the other hand, the identity-based CSOs are more dispersed along the vertical axis, with the above-mentioned tendency where presidents are placed closer to the lower end with activist backgrounds and charismatic leader figures (presidents of Red Cross, FoE, and Caritas) and directors rather closer to the mid-point of the vertical axis with pronounced managerial competences (directors of Caritas, FoE Europe, and Red Cross EU \& European region). One illustrative example is the case of Caritas. As a religious organization, it follows the internal rules of the Catholic Church. While the organization has a president who is a well-recognized religious figure (a bishop), when it comes to the director, they have appointed a leader who is Brussels-based and who has had a career trajectory in several welfare-oriented CSOs at the EU level.

What is also evident is that the environmental organizations are all placed in the upper-half of the space along the vertical axis, except for the president of FoE. The most common subject of study of the environmental CSO leaders seems to be environmental science and some other adjacent subjects such as biology, agriculture, food systems, and biodiversity. This is the case for both directors and presidents, with the exception of the director of the WWF who has previously worked in other EU-based CSOs with other issues. When it comes to the leaders of the CSOs working with social policy issues, we find more diverse subjects such as law, economics, business and management, and languages. The case of the director of the WWF is indeed worth noting because this is the only director of the environmental CSOs without a specific policy-relevant educational background. Her managerial competence and experience accumulated in the Brussels sphere seem to be the rationale for her recruitment.

It is worth noting that we find no individual leader placed in the lower-right corner of the space formed by the two axes in Figure 1. This might be interpreted as an incompatibility between having an activist background and being a charismatic leader figure and having Brussels-based and EU-specific types of capital.

\section{Conclusions and Discussion}

Despite the fact that our sample includes EU-level CSOs who are characterized by a high level of integration into EU institutions' formal and institutionalized ways of involving civil society, we observe diversity in the composition of the leaders in terms of the extent to which their 
career trajectories are embedded in the EU arena. At the same time, however, we do find systematic patterns regarding the distribution of different types of career trajectories along several comparative dimensions.

As shown in the previous section, the policy areas (social policy vs. environmental policy), types of leadership positions (presidents vs. directors), and types of organizations (umbrella organizations vs. identity-based organizations) provide us with some explanations as to the differences in the types of capital required to reach leadership positions in EU-based CSOs. We observe that the Brussels and specifically EU-based career trajectories are particularly prominent in the biographies of the leaders of the EU-based umbrella CSOs, and in particular among the directors rather than presidents.

Along the other important analytical dimension, the axis representing different career trajectories characterized by expert knowledge, managerial competence, and activist background, we see the clearest fault line between the CSOs working with environmental issues and those working with social policy issues, and to some extent between the umbrella CSOs and the identity-based CSOs. These results are in line with our expectation that expert knowledge would be more salient in the environmental policy area while activist background would be more salient in the social policy area. These differences might be linked to the expectation that CSOs within the social policy area not only have knowledge and expertise in the specific issues with which they work (as with the environmental organizations) but also are able to act as representatives of the societal groups they mobilize and support. For these organizations the activist background and the experiences at national and sub-national level of their leaders might provide the capital needed to be able to (at least claim) to be able to over bridge the gap between the EU-institutions and the communities of EU citizens.

The career trajectories of many directors can be understood as a personified version of the roles that the EU-based CSOs working closely with the EU-institutions are expected to play, namely providing information and expertise and mediating communication between the public and the EU, and thereby strengthening the legitimacy of the EU project (Saurugger, 2010). The skills and resources these CSO leaders have accumulated with their long-term career development in Brussels can be described as what Georgakakis and Rowell (2013) call "specifically European capital" that is valued by the EU institutional actors. The complex negotiation processes involving multi-level governance and complex webs of institutions require insiders with a "feel-for-the-game" (Savage \& Silva, 2013, p. 113) in Brussels. It is plausible that the leaders of the peak EU-based CSOs have also developed a shared, common political vision and culture of European integration as a result of their long socialization process (Georgakakis, 2017).

In contrast, for many of the presidents of the CSOs studied here their careers have been built up at the grass roots, national, or international level. These leaders de- liver on aspects such as representativeness, embeddedness in national contexts, and experience in specific policy issues at different governance levels. Their activist backgrounds seem to carry a certain symbolic capital among the identity-based CSOs because some of the individuals reached their leadership positions (mostly presidents) at the EU level exclusively based on their engagement outside of the EU arena. The fact that skills, experiences, and reputation accumulated outside of the EU arena carry important symbolic value in becoming the leader of EU-based CSOs (although concentrated to presidents) also means that the autonomy of the field of EU civil society is not complete.

A possible functionalistic explanation for the observed differences between the leadership positions could be that these presidents counterbalance the image of the EU-based CSOs being a part of an elitist project as has been presented by some national CSOs and some EU member states (Ruzza, 2019, p. 136). Alternatively, the leadership positions of the individuals with types of capital derived from other contexts beyond the EU arena might be interpreted as part of an on-going power struggle between the permanent and temporary agents among the CSO leaders who are active at the EU level, the latter constantly challenging this EU capital through capital accumulated and recognized outside of the field of Eurocracy.

Finally, we would like to return to our original question of whether EU civil society elites can burst the Brussels' bubble. Based on our results, if we consider both presidents and directors to be part of the EU civil society elites, we would argue that they can burst it. By allowing separate roles and career trajectories for presidents and directors, the CSOs can keep one foot in the Brussels bubble and one outside. However, the fact that we have found no CSO leader who clearly combines an activist background and EU-specific capital makes us wonder about whether these types of capital might be mutually exclusive and are therefore a sign that the Brussels bubble is hard to burst, at least at the level of individual career trajectory.

This article extends previous studies on the career trajectories of political actors in the field of Eurocracy by testing the theoretically and empirically motivated field dynamic in the EU arena in a novel organizational population. The distinction between EU capital and non-EU capital turned out to be fruitful in studying CSO leaders. A similar approach could be applied in future research where a larger number of leaders and organizations are included, preferably combining a quantitative variant of relational analysis method such as Multiple Correspondence Analysis in order to systematically address the broader map of the EU field of CSOs.

\section{Acknowledgments}

The article was written as a part of the project "Civil Society Elites? Comparing elite composition, reproduc- 
tion, integration and contestation in European societies," funded by the Swedish Foundation for the Humanities and Social Sciences (2018-2023). We thank anonymous reviewers who provided insightful comments. We also thank Carmen Cárdenas Elvira and Franziska Böhm for their assistance in data collection.

\section{Conflict of Interests}

The authors declare no conflict of interests.

\section{References}

Beauvallet, W., \& Michon, S. (2013). MEPs: Towards a specialization of European political work? In D. Georgakakis \& J. Rowell (Eds.), The field of Eurocracy. Mapping EU actors and professionals (pp. 16-34). New York, NY: Palgrave.

Bourdieu, P. (1994). Rethinking the state: Genesis and structure of the bureaucratic field. Sociological Theory, 12(1), 1-18.

Cichowski, R. A. (2007). The European court and civil Society. Litigation, mobilization and governance. New York, NY: Cambridge University Press.

Coen, D., \& Richardson, J. (2009). Lobbying the European Union: Institutions, actors and issues. Oxford: Oxford University Press.

Cullen, P. (2003). Sponsored mobilization: European Union non-governmental organisations, international governance and activism for social rights (Doctoral Dissertation). State University of New York at Stony Brook, Stony Brook.

Dialer, D., \& Richter, M. (Eds.). (2019). Lobbying in the European Union. Strategies, dynamics and trends. Berlin: Springer.

Dür, A., \& Mateo, G. (2016). Insiders versus outsiders: Interest group politics in multilevel Europe. Oxford: Oxford University Press.

Ellersgaard, C. H., \& Larsen, A. G. (2020). The craft of elite prosopography. In F. Denord, M. Palme, \& B. Réau (Eds.), Researching elites and power. Theory, methods, analyses. Berlin: Springer.

European Commission. (2001). European governance: $A$ white paper (COM (2001) 428). Brussels: European Commission.

European Commission. (2006). Green paper 'European Transparency Initiative' (COM (2006) 194). Brussels: European Commission.

Fligstein, N. (2008). Euroclash: The EU, European identity, and the future of Europe. Oxford: Oxford University Press.

Georgakakis, D. (2017). European civil service in (times of) crisis. A political sociology of the changing power of Eurocrats. London: Palgrave.

Georgakakis, D., \& Lebaron, F. (2018). Yanis (Varoufakis), the minotaur, and the field of Eurocracy. Historical Social Research, 43(3), 216-247.

Georgakakis, D., \& Rowell, J. (Eds.). (2013). The field of Eu- rocracy. Mapping EU actors and professionals. New York, NY: Palgrave.

Greenwood, J. (2007). Interest representation in the European Union (2nd ed.). Basingstoke and New York, NY: Palgrave Macmillan.

Héritier, A. (2012). Formal and informal institutions in the EU's legislative process. In T. Christiansen \& C. Neuhold (Eds.), International handbook of informal governance (pp. 335-353). Cheltenham: Edward Elgar.

Johansson, H., \& Kalm, S. (Eds.). (2015). EU civil society: Patterns of cooperation, competition and conflict. London: Palgrave.

Johansson, H., \& Lee, J. (2014). Bridging the gap: How do EU-based civil society organisations acquire their internal representation? Voluntas, 25(2), 405-424.

Johansson, H., \& Lee, J. (2015). Competing capital logics in the field of EU-level CSOs: Autonomy from or interconnectedness with the EU? In H. Johansson \& S. Kalm (Eds.), EU civil society: Patterns of cooperation, competition and conflict (pp. 61-80). London: Palgrave.

Kendall, J. (Ed.). (2009). Handbook on third sector policy in Europe: Multi-level processes and organised civil society. Cheltenham: Edward Elgar Press.

Khan, S. R. (2012). The sociology of elites. Annual Review of Sociology, 38, 361-377.

Kohler-Koch, B., \& Rittberger, B. (Eds.). (2007). Debating the democratic legitimacy of the European Union. Lanham: Rowman \& Littlefield Publishers.

Kröger, S., \& Friedrich, D. (Eds.). (2012). Representation in the European Union: Coping with present challenges to democracy? Houndmills: Palgrave Macmillan.

Magone, J. M., Laffan, B., \& Schweiger, C. (Eds.). (2016). Core-periphery relations in the European Union: Power and conflict in a dualist political economy. London: Routledge.

Maloney, W. A., Jordan, G., \& McLaughlin, A. M. (1994). Interest groups and public policy: The insider/outsider model revisited. Journal of Public Policy, 14(1), 17-38.

Meeuwisse, A., \& Scaramuzzino, R. (2019). Europeanization, civil society, and the Swedish welfare state. In A. Meeuwisse \& R. Scaramuzzino (Eds.), Europeanization in Sweden: Opportunities and challenges for civil society organizations (pp. 1-20). New York, NY: Berghahn Books.

Michel, H. (2013). EU lobbying and the European Transparency Initiative: A sociological approach to interest groups. In N. Kauppi (Ed.), A political sociology of transnational Europe (pp. 53-78). Colchester: ECPR Press.

Oleart, A., \& Bouza, L. (2018). Democracy at stake: Multipositional actors and politicization in the EU civil society field. Journal of Common Market Studies, 56(4), 870-887.

Robert, C. (2013). Expert groups in the field of Eurocracy. In D. Georgakakis \& J. Rowell (Eds.), The field of 
Eurocracy. Mapping EU actors and professionals (pp. 137-165). New York, NY: Palgrave.

Ruzza, C. (2007). Europe and civil society: Movement coalitions and European governance. Manchester: Manchester University Press.

Ruzza, C. (2014). Civil society actors and EU fundamental rights policy: Opportunities and challenges. Human Rights Review, 15, 65-81.

Ruzza, C. (2019). Populism, EU institutions and civil society. In L. Antoniolli, L. Bonatti, \& C. Ruzza (Eds.), Highs and lows of European integration (pp. 121-142). Cham: Springer.

Saurugger, S. (2010). The social construction of the participatory turn: The emergence of a norm in the European Union. European Journal of Political Research,
49(4), 471-495.

Savage, M., \& Silva, E. B. (2013). Field analysis in cultural sociology. Cultural Sociology, 7(2), 111-126.

Smismans, S. (2003). European civil society: Shaped by discourses and institutional interests. European Law Journal, 9(4), 473-495.

Stacey, J. (2010). Integrating Europe. Informal politics and institutional change. Oxford: Oxford University Press.

Trenz, H. J. (2009). European civil society: Between participation, representation and discourse. Policy and Society, 28(1), 35-46.

Vauchez, A., \& de Witte, B. (Eds.). (2013). Lawyering Europe: European law as a transnational social field. Oxford: Hart Publishing.

\section{About the Authors}

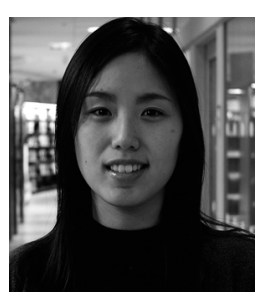

Jayeon Lindellee is a Post-Doctoral Researcher at the School of Social Work at Lund University in Sweden. Her current research is focused on understanding network structures in civil society organizations and the career patterns of their leaders in several European countries, including Sweden.

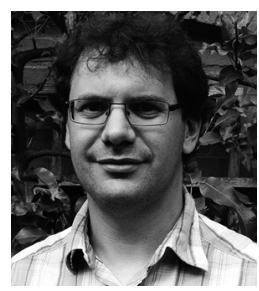

Roberto Scaramuzzino is an Associate Professor at the School of Social Work at Lund University in Sweden. His research interests include changes in the welfare and integration systems and the role of civil society organizations in different countries. He is currently working on a research program on Civil Society Elites in Europe. 